\title{
PENINGKATAN HASIL BELAJAR IPA DENGAN MENGGUNAKAN MODEL PROJECT BASED LEARNING BAGI SISWA SMP NEGERI 5 TEBING TINGGI
}

\author{
Pasuria Simbolon \\ Guru SMP Negeri 5 Kota Tebing Tinggi \\ Email: pasuria_simbolon@yahoo.com
}

\begin{abstract}
Abstrak
Penelitian ini bertujuan untuk untuk mengetahui peningkatan hasil belajar siswa kelas 8-4 dengan menggunakan model Project Based Learning di SMP Negeri 5 Tebing Tinggi Tahun Pelajaran 2013/2014. Subyek penelitian ini adalah Siswa kelas 8-4 SMP Negeri 5 Tebing Tinggi yang berjumlah 36 siswa. Penelitian ini dilakukan selama 3 bulan dimulai tanggal 12 Agustus 2013 sampai 10 Desember 2013. Dalam setiap kegiatan Siklus 1, Siklus 2 adanya observasi pelaksanaan pembelajaran yang dilakukan observaiser. Hasil penelitian pada siklus 1 menunjukkan sebanyak 24 siswa yang mengalami ketuntasan belajar atau $66 \%$ dan sebanyak 12 atau $34 \%$ siswa yang tidak mengalami ketuntasan belajar, hal ini disebabkan karena masih ada siswa yang belum memahami model project based learning. Pada siklus 2 Siswa yang mengalami ketuntasan belajar sebanyak 30 siswa atau 83\% dan Siswa yang tidak tuntas belajar sebanyak 6 siswa atau $17 \%$.
\end{abstract}

Kata kunci : Peningkatan, Project Base Learning, Hasil belajar

\section{PENDAHULUAN}

Pada Sekolah Menengah Pertama (SMP) mata pelajaran IPA bagi siswa sering menjadi mata pelajaran yang sangat kurang peminatnya. Banyak data dari berbagai sekolah hanya sedikit siswa di kelas yang mengerti, apalagi menguasai mata pelajaran IPA ini. Padahal mata pelajaran ini sangat erat hubungannya dengan perkembangan Ilmu Pengetahuan Alam dan perkembangan teknologi di dunia.

Perkembangan teknologi tidak akan lepas dari perkembangan dalam bidang Ilmu Pengetahuan Alam (IPA). Perkembangan dari bidang IPA tidak mungkin terjadi bila tidak disertai dengan peningkatan mutu pendidikan IPA, sedangkan selama ini pelajaran IPA dianggap sebagai pelajaran yang sulit. Hal ini dapat dilihat dari Nilai siswa pada mata pelajaran IPA ketuntasan belajar siswa yang rata-rata masih rendah, dari 36 siswa kelas 8-4 hanya 10 siswa atau $27 \quad \%$ siswa yang mengalami ketuntasan belajar

Sejumlah siswa yang tidak memiliki dorongan belajar untuk itu dibutuhkan suatu kegiatan yang dilakukan oleh Guru dengan upaya membangkitkan motivasi belajar siswa, misalnya dengan membimbing siswa untuk terlibat langsung dalam kegiatan yang melibatkan siswa serta Guru yang berperan sebagai pembimbing untuk menemukan konsep pembelajaran 
yang efektif pada mata pelajaran IPA.

Untuk memenuhi tujuan tersebut perlu diadakan tindakan penelitian, Guru harus mempunyai pendekatan pembelajaran yang tepat selama proses pembelajaran berlangsung. Salah satunya adalah dengan menerapkan model Pembelajaran Berbasis Proyek (Project Based Learning). Pembelajaran berbasis proyek adalah sebuah model pembelajaran yang inovatif yang menggunakan masalah sebagai langkah awal dalam mengumpulkan dan mengintegrasikan pengetahuan baru berdasarkan pengalamannya dalam beraktivitas secara nyata. Projec Based Learning (PjBL). Dalam model ini terdapat tahapantahapan dalam pelaksanaannya. Salah satunya adalah diskusi kelompok dimana siswa haru beraktivitas di dalam kelompok tersebut seperti mengeluarkan pendapat, memecahkan soal dan menjadi tutor sebaya. Model pembelajaran $\mathrm{PjBL}$ secara efektif akan membantu meningkatkan aktivitas belajar siswa karena mengharuskan siswa untuk aktif dalam tahapan diskusi kelompok. Dengan kegiatan ini diharapkan aktivitas belajar siswa akan meningkat yang berdampak pada peningkatan hasil belajar.

Berdasarkan kenyataan bahwa rendahnya hasil belajar siswa dalam belajar IPA, maka penulis tertarik untuk mengadakan penelitian dengan judul “ Upaya Meningkatkan Hasil
Belajar IPA Melalui Model Project Based Learning Bagi Siswa Kelas 84 SMP Negeri 5 Tebing Tinggi Tahun Pelajaran 2013/2014.

Rumusan masalah dalam penelitian ini adalah apakah model Project Based Learning dapat meningkatkan hasil belajar IPA Bagi Siswa Kelas 8-4 SMP Negeri 5 Tebing Tinggi Tahun Pelajaran 2013/2014?.

\section{TINJAUAN TEORI Pengertian Belajar}

Belajar adalah perubahan tingkah laku yang relatif menetap yang diakibatkan oleh pengalaman dan latihan. Clifford T. Morgan (1988) mengartikan belajar sebagai perubahan tingkah laku yang relatif tetap yang merupakan hasil pengalaman yang telah lalu. Menurut Slameto (2002) belajar adalah suatu proses usaha yang dilakukan individu untuk memperoleh suatu perubahan tingkah laku yang baru secara keseluruhan sebagai hasil pengalaman individu itu sendiri dalam berinteraksi dengan lingkungannya. Dari defenisidefenisi tersebut pengertian belajar yang lebih modern itu memuat tiga unsur penting belajar yaitu : perubahan tingkah laku, perubahan karena latihan atau pengalaman, dan hasilnya relatif menetap. Seseorang yang melakukan aktifitas belajar berarti telah melakukan aktifitas perubahan pada dirinya dan memiliki pengalaman baru. 
Berhasil atau tidaknya suatu proses belajar mengajar dapat dilihat dari hasil belajarnya. Hasil belajar seseorang dapat dilihat ditunjukan dari nilai yang dicapainya.

Hasil belajar semakin terasa penting untuk dipermasalahkan, karena mempunyai beberapa fungsi utama, yaitu :

a. Hasil belajar sebagai indikator kualitas dan kuantitas pengetahuan yang telah dikuasai anak didik.

b. Hasil belajar sebagai pemuasan hasrat ingin tahu. Para ahli psikologi biasanya menyebut hal ini sebagai tendensi keingintahuan (couriosity) dan merupakan kebutuhan umum pada manusia, termasuk kebutuhan anak didik dalam suatu program pendidikan.

c. Hasil belajar sebagai bahan informasi dalam inovasi pendidikan. Asumsinya adalah prestasi belajar dapat dilihat dijadikan pendorong bagi anak didik dalam meningkatkan ilmu pengetahuan dan teknologi dan berperan sebagai umpan balik (feed back) dalam meningkatkan mutu pendidikan.

Penilaian prestasi belajar menekankan pada informasi tentang seberapa jauh siswa telah mencapai kompetensi yang telah ditetapkan. Banyak alat ukur yang dapat digunakan untuk mengukur prestasi belajar, diantaranya berupa test atau test prestasi.
Prosedur test dalam mengukur hasil belajar mengandung nilai-nilai pendidikan yang sangat penting. Test membantu para guru dalam memberikan nilai yang lebih akurat dan lebih dapat dipercaya. Selain itu test berfungsi sebagai pemicu atau faktor pendukung munculnya motivasi dalam belajar. Siswa akan belajar lebih giat dan lebih keras bila mereka mengetahui nilai dan hasil belajar mereka. Memperoleh nilai yang baik dari suatu test hasil belajar merupakan suatu pengalaman yang menyenangkan.

\section{Pembelajaran IPA}

Ciri keilmuan yang melekat pada IPA adalah obyek keilmuannya adalah benda, didukung oleh fakta yang empirik dan logis, dengan metode ilmiah dan sistematika berfikir yang konsisten.Secara garis besar dapat diringkas bahwa IPA adalah : 1) Kualitas; pada dasarnya konsep-konsep IPA selalu dapat dinyatakan dalam bentuk angkaangka; 2) Observasi dan Eksperimen; merupakan salah satu cara untuk dapat memahami konsep-konsep IPA secara tepat dan dapat diuji kebenarannya; 3) Ramalan (prediksi); merupakan salah satu asumsi penting dalam IPA bahwa misteri alam raya ini dapat dipahami dan memiliki keteraturan. Dengan asumsi tersebut lewat pengukuran yang diteliti maka sebagai peristiwa alam yang akan terjadi dapat diprediksi secara tepat; 4) Progresif dan komunikatif; artinya IPA itu selalu berkembang kearah yang lebih 
sempurna dan penemuan-penemuan yang ada merupakan kelanjutan dari penemuan sebelumnya. Proses; tahapan-tahapan yang dilalui dan itu dilakukan dengan menggunakan metodeilmiah dalam rangka menemukan suatu kebenaran ; 5) Universalitas; kebenaran yang ditemukan senantiasa berlaku secara umum.

\section{Berdasarkan 5 kriteria IPA} tersebut maka proses pembelajaran IPA yang dilakukan Guru di kelas juga harus mengacu pada 5 ciri tersebut agar proses belajar mengajar dapat berlangsung dengan efektif. Guru yang mengajarkan IPA seharusnya melakukan aktifitas yang dimulai dari perencanaan, pelaksanaan kegiatan sampai evaluasi dan program tindak lanjut yang berlangsung dalam situasi edukatif untuk mencapai tujuan tertentu yaitu pengajaran IPA.

Sejalan dengan hasil belajar, maka dapat diartikan bahwa prestasi belajar IPA adalah nilai yang diperoleh siswa setelah melibatkan secara langsung/aktif seluruh potensi yang dimilikinya baik aspek kognitif (pengetahuan), afektif (sikap) dan psikomotor (keterampilan) dalam proses belajar mengajar IPA.

\section{Pembelajaran Berbasis Proyek (Project Based Learning)}

Menurut Nurhadi dalam Wulandari (215155:5), pembelajaran berbasis proyek merupakan pembagian dari pembelajaran berbasis tugas terstruktur. Pembelajaran berbasis tugas terstruktur (Project Based Learning) yaitu suatu pendekatan pembelajaran komprehensif dimana lingkungan belajar siswa didesain agar siswa dapat melakukan penyelidikan terhadap masalah-masalah autentik termasuk pendalam materi dari suatu topik mata pelajaran dan melaksanakan tugas lainnya

Pembelajaran berbasis proyek merupakan model pembelajaran yang inovatif, dan lebih menekankan pada belajar kontekstual melalui kegiatankegiatan yang kompleks. Fokus pembelajaran terletak pada prinsip dan konsep inti dari suatu disiplin ilmu, melibatkan siswa dalam inventisgasi dalam pemecahan dalam proses belajar mengajar dan kegiatan tugas-tugas bermakna yang lain, memberi kesempata siswa bekerja secara otonom dalam mengkonstruksi pengetahuan mereka sendiri, dan mencapai puncaknya untuk menghasilkan produk nyata.

Pada pembelajaran berbasis proyek, siswa diberikan tugas untuk mengerjakan proyek, membuat produk yang sesuai dengan materi yang dipelajari saat itu. Selain untuk memantapkan pengetahuan dan materi yang telah dimiliki siswa, pembelajaran ini juga memiliki potensi yang besar untuk memberi pengalaman belajar yang lebih menarik dan bermakna bagi siswa. 
Berdasarakan tahap-tahap diatas, dapat dijelaskan lebih rinci seperti berikut.

\section{Tahap perencanaan}

Perencanaan pembelajaran berbasis proyek mencoba mengaitkan materi yang dipelajari dengan situasi sebenarnya.Secara berurutan tahap perencanaan itu meliputi langkahlangkah sebagai berikut: a) Mempelajari pokok bahasan sesuai dengan produk yang akan dibuat; b) Merumuskan tujuan pembelajaran dengan menggunakan pendekatan berbasis proyek tersebut; c) Menentukan materi pelajaran dari pokok bahasan yang berkaitan dengan produk yang akan dibuat; d) Menentukan langkah-langkah dalam kegiatan belajar mengajar termasuk metode dan pendekatannya; e) Merencanakan organisasi kelas sesuai dengan kegiatan belajar mengajar (misalnya bekerja dalam kelompok); f) Menyiapkan formatformat persiapan untuk siswa; g) Merencanakan kegiatan tindak lanjut; h) Menyiapkan penilaian kegiatan belajar mengajar.

\section{Tahap pelaksanaan}

Langkah-langkah dalam tahap pelaksanaan adalah sebagai berikut:

a. Pada permulaan pembelajaran, guru menyampaikan produk yang akan dibuat siswa; b) Guru membagi siswa dalam beberapa kelompok kecil (misalnya per kelompok 5 orang); c) Tiap kelompok merencanakan kegiatan- kegiatan yang berhubungan dengan materi yang sesuai dengan produk yang akan dia buat. Guru membimbing setiap kelompok dan memberikan bantuan bila siswa memerlukannya. Tiap kelompok merangkai produk, mendiskusikan dan mencatat hasil diskusinya; d) Guru menjelaskan hal-hal penting yang perlu dilakukan ; e) Data yang terkumpul didiskusikan dan di presentasikan didepan kelas; f) Siswa-siswa memberikan komentar atau saran yang dicatat oleh anggota kelompok yang sedang mempresentasikan; g) Guru membantu memahami hubungan produk yang dibuat dengan materi yang dipelajari.

\section{Tahap tindak lanjut}

Salah satu kegiatan tindak lanjut yang sebaiknya dilakukan yaitu pameran. Pameran dapat berkisar antara pameran sederhana, misalnya pameran kelas yang dikunjungi kelas-kelas lainnya dari sekolah tersebut. Sampai pada pameran yang lebih luas misalnya pameran sekolah yang dikunjungi oleh sekolah lain. Pada tahap ini peneliti tidak menerapkannya.

\section{Tahap penilaian}

a. Penilaian dilakukan dengan tujuan untuk memperbaiki proses belajar mengajar dengan pendekatan berbasis proyek. Penilaian ditujukan untuk mengetahui apa yang dipelajari siswa. Penilaian juga digunakan untuk mengetahui apakah 
sikap-sikap dan keterampilan tertentu telah dimiliki siswa. b) Penilaian dapat dilakukan dengan tiga cara yaitu secara verbal misalnya dengan tanya jawab, secara tertulis misalnya dengan tes, atau penilian hasil kerja siswa seperti produk yang dihasilkan.

Menurut Thomas (2010) yang dikutip Wena (2011:145) pembelajaran berbasis proyek mempunyai beberapa prinsip, yaitu :

a. Sentralistis (centrality).

Model ini merupakan pusat strategi pembelajaran, dimana siswa belajar konsep utama dari suatu pengetahuan melalui kerja proyek.

b. Pertanyaan pendorong/penuntun (driving question).

Kerja proyek berfokus pada "pertanyaan atau permasalahan" yang dapat mendorong siswa untuk berjuang memperoleh konsep atau prinsip utama suatu bidang tertentu.

\section{c. Investigasi konstruktif \\ (contructive investigation).}

Proses yang mengarah kepada pencapaian tujuan, yang mengandung kegiatan inkuiri, pembangunan masalah, pembangunan konsep, dan resolusi. Dalam investigasi memuat pemecahan masalah, discovery, dan pembentukan model. Dalam kegiatan pembelajaran berbasis proyek ini harus tercakup proses transformasi dan konstruksi pengetahuan (Bereiter \& Scardamalia, 1999).

\section{d. Otonomi (autonomy).}

Dalam pembelajaran berbasis proyek dapat diartikan sebagai kemandirian siswa dalam melaksanakan proses pembelajaran, yaitu bebas menentukan pilihannya sendiri, bekerja dengan minimal surpervise, dan bertanggung jawab.

e. Realitis (realism).

Pembelajaran berbasis proyek harus dapat memberikan perasaan realitis kepada siswa, termasuk dalam memilih topik, tugas, dan peran konteks kerja, kolaborasi kerja, produk, pelanggan, maupun standar produknya. Jadi, guru harus mampu menggunakan dunia nyata sebagai sumber belajar bagi siswa. Kegiatan ini akan dapat meningkatkan motivasi, kreativitas, sekaligus kemandirian siswa dalam pembelajaran.

Pada pembelajaran berbasis proyek, guru lebih cenderung berperan sebagai fasilitator. Secara umum peran fasilitator adalah mementau dan mendorong kelancaran kerja kelompok, serta melakukan evaluasi terhadap efektifitas proses belajar kelompok. Menurut Moursund (1997) dalam Wena (215159:147) beberapa keuntungan dari pembelajaran berbasis proyek antara lain sebagai berikut:

a. Increased motivation. Pembelajaran berbasis proyek dapat meningkatkan motivasi belajar siswa 
terbukti dari beberapa laporan penelitian tentang pembelajaran berbasis proyek yang menyatakan bahwa siswa sangat tekun, berusaha keras untuk menyelesaikan proyek, siswa merasa lebih bergairah dalam pembelajaran, dan keterlambatan dalam kehadiran sangat berkurang.

b. Increased problem-solving
ability.beberapa
mendeskripsikanbahwa lingkungan
belajar berbasis proyek dapat
meningkatkan kemampuan
memecahkan masalah, membuat
siswa menjadi lebih aktif dan
berhasil memecahkan problem-
problem yang bersifat kompleks.

c. Improved library research skills. Pembelajaran berbasis proyek mempersyaratkan siswa harus mampu secara cepat memperoleh informasi melalui sumber-sumber informasi, maka keterampilan sisawa untuk mencari dan mendapatkan informasi akan meningkat.

d. Increased collaboration. Pentingnya kerja kelompok dalam proyek memerlukansiswa mengembangkan dan memperaktikan keterampilan komunikasi. Kelompok kerja kooperatif, evaluasi siswa, pertukaran informasi online adalah aspek-aspek kolaboratif dari sebuah proyek.

\section{e. Increased resource-management} skills. Pembelajaran berbasis proyek yang diimplementasikan secara baik memberikan pembelajaran praktik kepada siswa dalam mengorganisasi proyek, dan membuat alokasi waktu dan sumber-sumber lain seperti perlengkapan untuk menyelesaikan tugas.

Berdasarkan kutipan di atas dapat dijelaskan bahwa pemecahan masalah adalah suatu proses memperoleh sebuah kepuasan dalam memecahkan masalah yang kompleks, yang mana pada dasarnya dari masalah tersebut tidak jelas terlihat bagaimana cara mencari solusinya. Jadi aktivitas pemecahan masalah diawali dengan konfrontasi dan berakhir apabila sebuah jawaban telah diperoleh sesuai dengan kondisi masalah.

Dalam pembelajaran berbasis proyek, kemampuan pemecahan masalah yang baik adalah mampu mengenal karakteristik masalah yang sedang dihadapi dan menemukan inti dari masalah tersebut. Individu yang kurang mampu dalam memecahkan masalah umumnya dikarenakan mengalami kesulitan untuk menemukan inti masalah. Sebaliknya, individu dengan kemampuan yang baik dalam memecahkan masalah cenderung lebih mudah menemukan inti masalah, peka terhadap permasalahan yang dihadapi, dan aktif dalam memecahkan masalahnya. Apabila individu terbiasa menghadapi permasalahan, individu akan menjadi peka terhadap permasalahan yang muncul dan aktif memecahkannya. 
Ada 4 tahap yang dapat dilakukan dalam memecahkan suatu masalah, yaitu:

a) Memahami masalah/merumuskan masalah,

b) Membuat suatu rencana,

c) Melaksanakan rencana tersebut,

d) Memeriksa kembali hasil yang telah di peroleh.

Dalam pembelajaran berbasis proyek ini, siswa diminta mengkonstruksi sendiri pengetahuan mereka didalam konteks pengalaman sendiri untuk memechkan masalah yang dihadapinya. Dalam hal ini guru harus mampu merancang suatu kerja proyek yang mampu menumbuhkan rasa ingin meneliti, rasa untuk berusaha memecahkan masalah, dan rasa ingin tahu yang tinggi. Pada tiap siklus siswa diberikan test tertulis berupa soalsoal diakhir disiklus. Soal-soal tersebut digunakan sebagai bahan evaluasi siswa untuk mengetahui kemampuan mereka dalam memecahkan suatu masalah. Salah satu upaya untuk menumbuhkan kembangkan kecakapan kolaboratif dan kemampuan pemecahan masalah siswa adalah dengan menerapkan pembelajaran berbasis proyek. Pembelajaran berbasis proyek memiliki potensi yang amat besar untuk membuat pengalaman belajar yang lebih menarik dan bermakna bagi siswa. Melalui penerapan model Pembelajaran Project Based Learning dapat meningkatkan hasil belajar siswa kelas 8-4 SMP Negeri 5 Tebing Tinggi.

\section{METODOLOGI PENELITIAN}

Peneliti mengawali dengan pengajuan judul tentang penelitian yang akan dilaksanakan. Adapun subyek penelitian adalah siswa kelas 8-4 SMP Negeri 5 Tebing Tinggi semester I tahun 2013/ 2014 yang berjumlah 36 orang. Pada Penelitian tindakan kelas data yang dikumpulkan dapat berbentuk kuantitatif maupun kualitatif . Penelitian tindakan kelas tidak menggunakan uji statistik, tetapi dengan deskriptif.

Data kuantitatif yang berupa nilai dianalisis dengan menggunakan analisis deskriptif komparatif yaiu membandingkan nilai tes kondisi awal, nilai tes setelah siklus I dan II yaitu nilai dari hasil ulangan harian siswa kelas 8-4 SMP Negeri 5 Tebing Tinggi. Komponen pengajaran metode eksperimen adalah data kualitatif yang berupa observasi kegiatan guru, dan siswa serta data kuantitatif yang berupa nilai hasil ulangan harian siswa kelas 8-4. Model penelitian tindakan kelas yang digunakan peneliti adalah system spiral refleksi diri yang dikembangkan oleh Kemmis dan Taggart (1990: 11) yang dimulai dengan perencanaan, tindakan, pengamatan, dan refleksi. Masingmasing siklus terdiri dari dua kali pertemuan yaitu sebagai berikut;

Perencanaan

$$
\text { Sebelum }
$$

mengadakan

penelitian peneliti menyusun rumusan masalah, tujuan dan membuat rencana tindakan, termasuk 
di dalamnya instrumen penelitian dan perangkat pembelajaran.

\section{Pelaksanaan}

\section{a. Siklus I}

Dengan bimbingan guru, siswa membentuk kelompok. Guru melakukan pembelajaran di dalam kelas dengan menggunakan panduan perencanaan yang telah dibuat. Penerapan metode project based learning dilakukan dengan menugaskan kepada masing-masing kelompok untuk mendiskusikan materi yang diajarkan guru sesuai dengan materi Sistem gerak pada manusia dan hubungannya dengan kesehatan.

Pada saat kegiatan pembelajaran berlangsung guru sebagai peneliti dibantu oleh para observer lainnya untuk melakukan pengamatan, pendokumentasian, selain itu peneliti bertindak sebagai fasilitator, motivator dan sekaligus sebagai pengamat.

\section{b. Siklus II}

Guru melakukan pembelajaran kelas menggunakan panduan perencanaan yang telah dibuat. Materi yang diajarkan guru sesuai dengan materi Mendiskripsikan sistem pencernaan pada manusia dan hubungannya dengan kesehatan.

Pada Siklus kedua ini juga, suasana pembelajaran masing-masing kelompok dikondisikan agar tidak terlalu formal, maksudnya siswa bebas mengemukakan pendapatnya tentang materi ajar sesuai dengan kompetensi dasar yang ingin dicapai.

\section{Observasi/Pengamatan}

Pengamatan dilakukan peneliti sendiri dan dibantu oleh pengamat dan mencatat proses penerapan teknik kolaborasi.

\section{Refleksi}

Peneliti mengkaji melihat dan Mempertimbangkan atau dampak dari tindakan yang dilakukan berdasarkan lembar pengamatan yang diisi oleh pengamat. Tahapan tindakan ini dilakukan secara berkesinambungan sehingga diperoleh hasil yang optimal.

\section{HASIL PENELITIAN DAN PEMBAHASAN}

Hasil penelitian tindakan
kelas menunjukkan bahwa
pengamatan yang dilakukan oleh
mitra kolaborasi dan peneliti pada
aktivitas guru dan siswa melalui
penerapan model project based
learning pada mata pelajaran IPA
kelas 8-4 SMP Negeri 5 Tebing
Tinggi dapat dilihat pada Tabel 1
yaitu sebagai berikut:
yaitu sebagai berikut : 
Peningkatan hasil belajar siswa

\begin{tabular}{|l|c|c|c|}
\hline \multirow{2}{*}{ Keterangan } & \multicolumn{3}{|c|}{$\begin{array}{c}\text { Peningkatan Hasil } \\
\text { Belajar Siswa }\end{array}$} \\
\cline { 2 - 4 } & $\begin{array}{l}\text { Pra } \\
\text { Siklus }\end{array}$ & $\begin{array}{c}\text { Siklus } \\
1\end{array}$ & $\begin{array}{c}\text { Siklus } \\
2\end{array}$ \\
\hline $\begin{array}{l}\text { Persentase } \\
\text { ketuntasan } \\
\text { belajar }\end{array}$ & $27 \%$ & $73 \%$ & $83 \%$ \\
\hline $\begin{array}{l}\text { Jumlah } \\
\text { Siswa }\end{array}$ & 10 & 24 & 30 \\
\hline \multicolumn{3}{|c|}{ Berdasarkan pengamatan } \\
\hline
\end{tabular}

peneliti dari tindakan pra siklus, siklus 1 dan siklus 2 pada tabel 1 terjadi peningkatan ketuntasan hasil belajar siswa kelas 8-4 pada jumlah siswa dan persentase ketuntasan belajar. Hal ini dapat dilihat dari peningkatan jumlah siswa yang tuntas dari 10 siswa pada prasiklus menjadi 24 siswa pada siklus 1 dan 30 siswa pada siklus 2 kelas 8-4 dengan menggunakan model project based learning di SMP Negeri 5 Tebing Tinggi. Hasil observasi terhadap kegiatan guru di dalam kelas juga terjadi peningkatan . Model project based learning yang diterapkan pada siklus pertama ini berhasil secara psikologis yaitu dapat meningkatkan komunikasi didalam kelompok, mampu membuat siswa belajar secara mandiri dan siswa terlihat memperhatikan kegembiraannya untuk mengikuti proses pembelajaran. Namun demikian, pada siklus pertama ini, penerapan model pembelajaran Berbasis Proyek belum berjalan dengan baik dan optimal. Hal ini disebabkan karena siswa dan Guru belum memahami bahkan belum pernah menerapkan model ini dalam proses belajar mengajar. Pada siklus 2, antusiasme Guru maupun siswa sudah baik untuk melaksanakan model pembelajaran Pembelajaran Berbasis Proyek ini secara optimal. Keadaan ini terjadi karena baik Guru maupun siswa sudah pernah melakukannya sehingga metode ini tidak lagi merupakan keadaan yang asing dan baru bagi Guru maupun siswa.Hasil observasi terhadap kegiatan siswa pada siklus 1 mayoritas siswa $(74,5 \%)$ belum memperlihatkan kegembiraan dalam mengikuti proses pembelajaran. Mereka masih terlihat bingung, kaku dalam model pembelajaran Berbasis Proyek, Pemahaman siswa terhadap materi pelajaran yang diberikan Guru dengan model pembelajaran Berbasis Proyek juga masih belum memberi kontribisi yang signifikan terhadap pengingkatan kemampuan mereka untuk memahami pelajaran. Hal ini terbukti dari 36 siswa, sejumlah 83\% masih menyatakan cukup dan kurang memahami materi pelajaran yang disajikan Guru kepada mereka. Berdasarkan hasil observasi penelitian dan kedua observer ketika proses belajar mengajar berlangsung pada siklus 2, mayoritas siswa $(87,2 \%)$ sudah memperlihatkan kegembiraan dalam mengikuti proses pembelajaran. Mereka terlihat bersemangat, gembira dalam mengikuti model pembelajaran Pembelajaran Berbasis Proyek, yang mengaharapkan keterlibatan mereka secara total dalam diskusidiskusi kelompok. Pemahaman siswa terhadap materi pelajaran yang 
diberikan Guru dengan model pembelajaran Pembelajaran

Berbasis Proyek juga sudah memberi kontribusi yang signifkan terhadap peningkatan kemampuan mereka untuk memahami pelajaran. Hal ini terbukti dari 36 siswa, sejumlah 53,2\% menyatakan Sangat Baik dan $38,3 \%$ menyatakan Baik dalam memahami materi pembelajaran yang disajikan Guru kepada mereka. Pemahaman siswa terhadap materi pelajaran yang diberikan Guru dengan model Pembelajaran Berbasis Proyek juga sudah memberi kontribusi yang signifikan terhadap peningkatan kemampuan mereka untuk memahami pelajaran. Dari hasil tes ini dapat dilihat bahwa hasil belajar dengan menggunakan pembelajaran project based learning telah mampu meningkatkan pemahaman siswa mengenai materi pelajaran IPA sesuai dengan indikator yang telah ditentukan sehingga tidak perlu lagi dilanjutkan pada siklus berikutnya dan dikatakan berhasil.

\section{SIMPULAN DAN SARAN}

Dari hasil siklus I menunjukkan bahwa terjadi peningkatan jika dibandingkan dengan sebelum pembelajaran dengan model pembelajaran Project Based Learning dari 36 siswa yang mengalami ketuntasan belajar sebanyak 24 siswa ( 66) dan siswa yang tidak mngalami ketuntasan belajar sebanyak 12 siswa ( $34 \%$ ). Pada siklus II siswa yang mengalami ketuntasan belajar sebanyak 30 siswa $(83 \%)$ dan siswa yang tidak mengalami ketuntasan belajar sebanyak 6 siswa ( 17\%) . Dari perolehan siklus II hasil Belajar siswa sudah mencapai ketuntasan klasikal $75 \%$. Dari data hasil Belajar model Project Based learning dapat meningkatkan hasil belajar siswa kelas 8-4 SMP Negeri 5 Tebing Tinggi Tahun Pelajaran 2013/2014

Atas dasar simpulan hasil penelitian tindakan kelas di atas, penulis memberikan saran sebagai berikut :

a. Bagi siswa

Penelitian tindakan kelas ini terbukti bahwa dengan menngunakan model Project Based Learning diharapkan dapat menjadi solusi untuk meningkatkan hasil belajar siswa, tidak hanya pada mata pelajaran IPA saja tetapi solusi pada mata pelajaran yang lain

b. Bagi Guru

Model pembelajaran Projec base Learning terbukti dapat meningkatkan hasil belajar siswa sehingga diharapkan bagi guru supaya dapat menggunakan Pembelajaran Project Based Learning untuk meningkatkan hasil belajar siswa.

c. Bagi Sekolah

Model Pembelajaran Project Based Learning supaya dapat dikembangkan lebih lanjut oleh guru sehingga model pembelajaran ini lebih baik dan 
tujuan pembelajarannya lebih efektif dan efisien.

\section{DAFTAR RUJUKAN}

Abdullah, A,E. 1989. Pokok-pokok Layanan Bimbingan Belajar. Ujung Pandang: Fakultas Ilmu Pendidikan IKIP Ujung Pandang.

Abdurrahman, H. 1990. Pengelolaan pengajaran. Bandung: Tarsito.

Ahmadi, Abu. 1998. Didatik Metodik. Cet.II. Semarang: CV. Toha Putra.

Ali, M. 1993. Guru dan Proses Belajar Mengajar. Bandung: Sinar Baru Algesindo.

Anonym, 1998. Garis-garis Besar Haluan Negara. Jakarta: Departemen Pendidikan Nasional.

Arikunto, S. 2001. Prosedur Penelitian dan Penilaian Hasil Belajar. Jakarta : Bina Aksara.

Boediono, 1998. Pembinaan Profesi Guru dan Psikologi Pembinaan Personalia. Jakarta ; Departemen Pendidikan dan Kebudayaan.

--------, 1993. Dasar-dasar Evaluasi dan pendekatan Prektek. Jakarta : Bina Aksara. 